\title{
Prevention of Violence and Sexual Abuse in Early Childhood Through I mplementation of Sex Education in the Perspective of the Sunnah
}

\author{
Lely Camelia and Ine Nirmala
}

Received: 24102016 / Accepted: 1312 2016 / Published online: 13122016

๑ 2016 Association of Indonesian Islamic Kindergarten Teachers Education Study Program

\begin{abstract}
This article discusses the conceptual studies on the implementation of early childhood sex education according to Islamic perspective. The number of cases of violence and sexual abuse against children has recently made various parties, no exception for parents, that must be alert to the threat. The big point of that is in 2015 when Indonesian Child Protection Commission said that cases of violence and abuse against children is a latent danger for the children of Indonesia. Several attempts have been made, some like starting to give a sex education early for parents and children, limiting the viewing access to pornography, limiting the contents of pornography on the internet and games, and stopping the attempts of the perpetrators in violence and sexual abuse against children by give them the weightest punishments. Rasullullah SAW as good role model has provided some guidance for us on how to educate children in detail, not only about early sex education, but also how to educate them since they are in the loins of their father. W ith reference to the sunnah that has showed by our Prophet to us, we as teachers and parents can apply it in everyday life, that will have a positive impact on children and the environment in the prevention of violence and sexual abuse against children.
\end{abstract}

Keywords sex education, children, islamic perspective, Prophet's sunnah perspective

\section{Introduction}

Every child born into the world in a state of purity, the parents and the environment that will shape his/her character. Is good character or bad depending on how their parents educated them, and also the environment in which they lived. In the early periods of life, the child will receive direction from both parents. Then the responsibility to direct the child to the kindness, is on the shoulders of the parents. Because, the early period of a child's life are the most important period that most critical period.To grow properly, children need a good environment as well as Zakiah Daradjat said that everything that is around humans influence the development of education either directly or indirectly. If the environment in which a child is bad, it will be very influential in his life ahead. In fact, he/she could slide on unlawful thing because of delinquent problem of children (juvenile delinquency). Environment plays an important role in the growth and development of children, especially when the child is still in the early ages 0-6 years. 
Islam is a heavenly religion, that is universal, revealed by Allah Almighty to Prophet Muhammad SAW as a supplement and complement of syaria religions divine before it. As evidence of its universality there is one aspect that has relevance to the daily life of the M uslim community, the value of education (paedagogis) that be able to lead human into the complete person through the process of directed phasing (Amirudin 2016: 1)

Cases of violence against children is a social problem that has a big impact for the health aspects that affects adversely the growth process of children both physically and psychologically, especially the psychological trauma impact on the quality of life of children who are in the process of growth and development. The Islamic system is a unique system of life, which the State actually has responsibility for implementing the rules of Islam as a whole in order to manage the entire affairs of the people, so that people get a guarantee of security and prosperity in a fair and thorough.

But in fact the violence can not be denied still going on, as published in Kompas daily on March 9, 2016, cases of violence like sexual abuse in Kampung Rawa Indah, Kelapa Gading, against a girl aged 15 years, that was conducted by his own uncle since she is 6 year old.

According to the Indonesian Child Protection Commission (KPAI), cases of violence against children tend to increase every year. KPAI's report shows in the last 3 years there happens every 45 months of violence against children (Ferri, 2015). As a prevention, parents and the neighborhood that closest to them, that are the most appropriate to provide early sex education. Parents should not be taboo and was reluctant in providing information to children associated with sex education.

With holding firmly to the teachings of the religion derived from the Quran and Sunnah, parents can practice in ways that have exemplified the Prophet related to sex education to children, in order to prevent the negative behaviors of children who can direct the child to violence behavior and sexual abuse in early childhood.

\section{The concept of sex education to the early childhood in the perspective of Islam}

In fact the public understand the concept of sex education as providing information about the genitals and various ways or positions in sexual intercourse with the opposite sex. So many parents who prefer to avoid talking about sex education with children and think that it is a taboo and feel so embarrassed when talking about anything related to sex education.

Some understanding of sex education below reveals that sex education is not seen from the narrow sense that discuss sex or ways and positions in sexual intercourse, but sex education according to Syamsudin (1985: 14) is in part an attempt to lead a person to be able to understand right about the meaning and function of his/her sexual life so they can use and place them well throughout their lives.

So also with the definition of sex education according to Calderone (in Suraji, 2008), is some lesson to strengthen family life, to foster self-understanding and respect for themselves, to 
develop the capabilities to socialize with others in a healthy way and to build sexual and social responsibility.

Thus sexual education can be interpreted as an effort to provide the knowledge of its aspects, understanding, purpose, and consequently covering the fields of biological, psychological and moral psychosocial with instill ethics and religious commitment to respect themselves. Therefore, sexual education is necessary for children, with the aim of guiding and nurturing someone to understand the meaning, function, and sexual purposes so can use it properly, correctly and not illegal.

Imam Al-Ghazali said that the introduction of giving sex education to the chidren can begin early in the way the parents nurturing and breastfeeding by the good and shaleha women and feeding them with a good nutrition. When children are able to distinguish something, then it should be further enhanced supervision for example is to embed bashfulness, forbid them to wear silk and colored clothes, kepep them from contact with peers who like glamour style, keep them from reading a poem containing and prohibited sexual acts furtively, not allowe them to leave purification and prayer, and also show them the limit of religious norms (Amirudin 2016: 6).

By thus right understanding and selecting ways of how to communicate and give an information about sex education to children, will deliver them becomes a human being who are able to keep themselves out of forbidden acts and aware of the threats and warnings of fornication and has a religious obvious path (Sulistyo 2005 : 19).

\section{Sexual development of early childhood}

In Santrock (2007: 45) theory of psychoanalysis Sigmund Freud divide the human sexual life developmental stages to the following five:

1. Oral phase (0-1 years) is a period where both physical and emotional satisfaction focused on the area around the mouth. The need for food is the most important requirement for the physical and emotional factors that are to be immediately satisfied.

2. Anal phase (1-3 years) is a period where the sensation of pleasure centered on the area around the anal and all the activities associated with the anal area. At this time the child began to be introduced to the "toilet trainning" that was introduced about a sense of urge to urinate and defecate.

3. Phalic phase (3-6 years) is a period where the genitals are the most important part, children like to play genitals and it sometimes makes the parents feel unhappy with that. This period is very important for the development of the child's gender identification, how should the boys or girls behave, dress and play. If at this time the environment does not support the child to identify himself properly, then the child will have a bias or ambiguity in identifying him/her self as a male or female.

4. Latency phase (7-10 years) is a period where the sexual needs of children are not seen again, children are more interested in activities that involves physical and intellectual skills that are 
distributed in school and sports. At this time the children are able to identify with either as a male or female, play and do activities with other boys as well as girls.

5. Genital Phase (10-15) is the period where it begins there is interest to the opposite sex, begin a relationship with the opposite sex, learning to love, need for affection and love of the opposite sex.

The importance of understanding the concept of self (self concept) of the children early will affect the sexual behavior of his/her mature. The self-concept is built from a child age 1 year that begin to identify themselves according to sex and started to change since the age of about 4 years, where children begin to view the characteristics to describe him/her self. (Papalia in Mil 2015: 147). Understanding the concept of self is just like he/she can identify their self (male or female), appreciate and respect their self, to understand behaviors that may potentially demeaning and can going to the sexual harassment.

\section{Stages of sexual introduction to the early childhood}

Hurlock (2003: 129) said that children has own the sexual interest, which like we knows that they tned to find characteristics and behaviours that associated with a particular gender with the characteristics of the opposite sex-specific and characteristic as opposed to the opposite sex. The introduction of early sex education is considered and very important thing that given to the age of 1 year old children that they are already aware of the environment around them. Whether he/she was amale or female.

Similarly with other education, sex education too, is a process of communication for the provision of continuous information to the children. At an early age, children are in the stage of concrete thinking and concentration span of no more than 5 minutes, therefore parents need to know the right and effective way to communicate sex education to children. Use a reasonable statement, clear, honest (not concealed / engineered) and using simple language appropriate to the age of children to build an understanding of sex education that is good and positive. The following table provides an introduction of sex eduxation according to the age of children:

Tabel 1

Phases of providing an introduction of sex education according to the appropriate age of children

\begin{tabular}{ll}
\hline Age & Phase \\
\hline $\mathbf{2 0}$ months & $\begin{array}{l}\text { Children shows curiosity and tend to explore the genitals area, by holding and } \\
\text { touching repeatedly, the child does not have romantic fantasies like what was } \\
\text { envisioned adults. Parents do not have to react strongly to that child's behavior, } \\
\text { because the child's genitals is no different with the fingers, nose or other organs }\end{array}$ \\
& $\begin{array}{l}\text { At this stage, children begin to recognize the difference between the sexes and can } \\
\text { identify differences in male and female genitals area. Boys are like father and girls } \\
\text { like mother. }\end{array}$ \\
& $\begin{array}{l}\text { Parents can introduce the other organs according to its function. Likewise also the } \\
\text { name and function of the genitals. A void using terms that are not specifically } \\
\text { related to the name of sex because it may cause confusion in children. Using }\end{array}$ \\
\hline
\end{tabular}


biological terms is an appropriate way for the introduction of the name of gender.

$\mathbf{1 - 2}$ years
At this stage the children is at phalic phase or pleasure obtained on the genital
area where the children feel the sensation of pleasure when touched their genitals
and is very interesting for children.
At this time, parents can distract the child by taking playing, reading story books
and other activities that can distract a child from playing genitals.
At this stage children start asking about things related to sex as like the question
from where the baby out, and others.
Parents must correctly answer this question because the introduction of the
genitals and sex is the first step to protect children from sexual abuse and violence
againts children.
At this age parents are able to provide information about the development of
reproductive organs by using the media or tools that familiar and close tothe
child, such as books or educational VCD impression that describes the genitals
area that will change by age to age.
Parents can teach children to be able to protect themselves and dare to say no if
someone tries to persuade them to undress despite the attractive inducements and
rewards.

\section{The application of sex education according to the sunnah}

Islam recommends for parents to always pay attention to the surroundings, as well as the implementation of the sex education materials have not become a special material that is taught in an educational institution. Although the foundation in general about sex education are included in the values of the Islamic texts. Parents as the first party that has responsibility for the safety of their children undergo the developmental stages (physical, cognitive, emotional language, intellectual, sexual, social, moral and religious) that they have to pass it on.

Here are some ways to teach sex education in early childhood, as exemplified by the Prophet M uhammad:

1. Give a good name to the children. Allah is beautiful and loves beauty. A mong the beauty is to give a good name and does not give meaningful names bad. Giving names to male gender - male or female. A void naming create hesitations or that have double meanings

2. Give children the toilet training. A hmad said that there was a baby girl who wet when she was on the lap of the Prophet. Then the Prophet did not feel disturbed by the incident, but the Prophet just asked for some water and immediately gets spray it to the wet. Children aged 1 year can already be given an explanation of how to toilet trainning correct. Each before sleeping and after waking up accustomed to the toilet and the child accustomed to express what he felt when going to urinate and defecate. Parents can see the movements of children when going to urinate and defecate, so it can go directly to the toilet.

3. Circumcising and keeping genital cleanliness. A bu H urayrah said: The fitrah are in the five, circumcision, shaving the pubic hair, shaving the whiskers, cut nails and plucking the armpit. Teach children to keep the genitals to clean and healthy while also teaching children about unclean. Kids should also be taught to urinate in the right place (toilet training). In this way the child will be formed on the cautious attitude, independent, loves cleanliness, 
capable of self-control, discipline, and morality is concerned about ethical manners of doing lavatory.

4. Instilling shyness to the children. Shyness should be imparted tothe children early. Do not get used to children, even though they are small, naked in front of others; for example when getting out the shower, change the clothes, and so on. And get children to always hide his nakedness and to don't allow them self to shower with the children.

5. Prohibit boys resembling girls. Give clothes and toys that match with the gender of the child, so that children are accustomed to act in accordance with nature. The child should be treated according to their gender. Ibn A bbas ra. said: "Rasulullah has cursed the men who pretended to imitate women and women who pretend to imitate men. (Reported by alBukhari). So also with the selection of clothing material in use, Rasulullah said men of my people forbidden wearing silk and gold and the women may do (wearing both of them)".

6. Teaching sex education through prayer. At the age of 7 years old child begins to distinguish who is male and who is female. Children have started accustomed to pray 5 times a day. Very clear in prayer there isspecial line for the men there is for women only. We can provide an explanation of how cover the aurat for men and women. That man from the navel to the knees and women's entire body except the face and palms.

7. Separating children's bed and prohibiting them sleep on their stomach. When the children are in 10-year-old, his sexual instincts begin to grow. The child must be treated carefully to ward off all the causes of the damage, distortions and moral decadence. M essenger of Allah said: "Instruct your children to pray when they are in the age of seven and beat them for leaving when they are ten years old, and separate their beds. If someone of you marrying slave or servant, let it not to see the genitals area because the real part below the navel to the knee, including genitals area". 10-year old should not be allowed to sleep daam one mattress. But each should sleep apart from the others. This is the guidance of separation as a form of obedience to the commands of the Prophet. A bu Dawud narrated that Rasulullah forbid us to sleep on our stomach / tummy because it is the way of the wrath of Allah. According to another hadith narration that sleep on the stomach is the way of the hell's elderly. No doubt that sleep on the stomach can cause the despicable friction, arouse lust and arouse the sexual instincts.

8. Telling the children the specific time if they want to go to the parent's room. (Asking Permission In 3 Time). Three provisions of time that children were not allowed to enter the parent's room before ask permission are: before subuh prayer, the middle of the day, and after isya'prayers. With this kind of education children will be a child who has a sense of propriety and good ethics.

9. Educating children to always maintain their eye sight. It's so natural for every human being going to be attracted to the opposite sex. However, if that natural instinc is allowed without control, it will only damage the human life itself. Therefore, keep children away from the image, movie, or reading contains elements of pornography. In the history of Ibn 
Khuzaimah mentioned that Rasullullah said: "my niece, on this day, who would lower his gaze, save his genitalia and his tongue, his sins will be forgiven".

10. Ordering the daughters for using the hijab when they has baligh. Allah has ordered to women and the young gilrs to wear the hijab. In accordance with the word of God, which means: "O Prophet, say to the wives - wives, children - daughters, and wives - wives of the believers, Let them throughout their bodies stretched out her head scarf" (Al - A hzab: 59). Rasulullah directly carry out God's command to all wives, daughters and all women of mukmin to use hijab, untuil now that the hijab has been known and entrenched among all muslim women, both young and adult. From some discussion of sex education by way of the Sunnah Rasul, may serve as an example that is appropriate and relevant to the present situation. In hopes of reducing violence and sexual abuse in children.

\section{Conclusion}

Sex education is not about supporting a child for sexual intercourse or carry the children to the negative thing that leads towards pornography. But sex education can be interpreted as an effort to provide the knowledge of its aspects, understanding, purpose, and consequently covering the fields of biological, psychological, and psychosocial inculcate moral ethics and religious commitment to respect themselves. Therefore, sexual education is indispensable for children, with the aim of guiding and caring them to understand the meaning, function and sexual purposes so as to channel it properly, correctly and not illegal. Sex education to the children is a necessity given by using the approach of religion, health, hygiene, social, moral, and so on. The education provided must correspond with the level of understanding and the age of the children so that it can prevent plunged into deviant behavior that can lead to violence and sexual abuse in children.

\section{References}

Amirudin. 2016. Pembinaan Perilaku Seksual Remaja Dalam Perspektif Imam AI - Ghazali. Bandung : Multikreasindo.

Asosiasi Pendidik Guru PAUD Indonesia. Jurnal Pendidikan Anak Usia Dini Vol 9 Edisi 2 November 2015. Jakarta : UNJ Press.

Darajat, Zakiyah. 2010. IImu Jiwa A gama. Jakarta: Bulan Bintang

Hurlock, Elizabeth. 2003.Developmental Psycology (A life Span Approach). Boston : The McGrawHills

Jamal Syaikh Abdurrahman. 2010. Islamic Parenting: Pendidikan Anak M etode Nabi. Solo: Aqwam

Santrock, John W. 2007. Child Development.Boston: The M cGrawHills.

Suraji dan Sofia Rahmawatie. 2008. Pendidikan Seks Bagi Anak: Panduan Keluarga Muslim. Yogyakarta: Pustaka Fahima. 
Syamsudin. 1985. Pendidikan Kelamin dalam Islam. Solo : Ramadhani.

Sulistyo, Rono. 2005. Pendidikan Seks. Bandung: Ellstar Offset. 